\title{
EVALUATION OF CUSTOMER SATISFACTION WITH PRODUCTS IN THE SELECTED COMPANY
}

\author{
Ing. Lenka Kyjaková; doc. Ing. Renáta Bašková, Ph.D. ${ }^{1}$
}

${ }^{1}$ TU Košice, Stavebná fakulta, Vysokoškolská 4, Košice 04200, Slovensko

\begin{abstract}
Design and introduction of quality management system in the organization are affected by changing conditions, needs, specific objectives system, providing products and using a process. On a global scale, a large number of organizations use most widespread quality management systems based on models presented in the standards ISO 9000. This paper focuses on system of quality control in the selected company. Based on the questionnaire survey it was measured a customer satisfaction. According to the results of the survey, there were specified objectives of quality to enhance customer satisfaction.
\end{abstract}

Key words: quality management systems, questionnaire survey, customer satisfaction

\section{INTRODUCTION}

Quality is a universal value and has become a global issue. In order to survive and be able to provide customers with good products, organisations are required to ensure that their processes are continuously monitored and product quality is improved. Quality control is the part of quality management that ensures products and service comply with requirements. It is a work method that facilitates the measurement of the quality characteristics of a unit, compares them with the established standards, and analyses the differences between the results obtained and the desired results in order to make decisions which will correct any differences [1]. Quality assurance is a set of planned and systematic actions to ensure that products and services comply with specified requirements. It not only involves checking the final quality of products to avoid defects, as is the case in quality control, but also checking product quality in a planned way in all the production stages. It is the development of work and product design procedures to prevent errors from occurring in the first place, based on planning backed up by quality manuals and tools. When a consensus has been reached on the requirements of a quality management system, it is possible to define a series of generic standards applicable to any type of organisation. The international standards, generically called ISO 9000, are the most widespread and generally accepted in developed countries [2].

Standards in the ISO 9000 family include: [3]

- ISO 9000: 2005 Quality management. (covers the basic concepts and language)

- ISO 9001: 2008 Quality management systems - Requirements. (sets out the requirements of a quality management system)

- ISO 9004: 2009 - Managing for the sustained success of an organization - A quality management approaches. (focuses on how to make a quality management system more efficient and effective)

- ISO 19011: 2011 Guidelines on internal and external audits of quality management systems not use other formatting than the allowed styles. (sets out guidance on internal and external audits of quality management systems.) 
The purpose of this paper is to present the implementation of quality control in selected company and identify customer satisfaction on based the questionnaire survey.

\section{RESEARCH METHOD}

Quality can be defined as fulfilling specification or customer requirement, without any defect. A product is said to be high in quality if it is functioning as expected and reliable. Quality control refers to activities to ensure that produced items are fulfilling the highest possible quality[4], [7]. The study aims at exploring of the customer satisfaction with the quality products in Slovakian organization. Customer satisfaction with the products of the selected Company was measured based on a questionnaire survey.

\subsection{Background of the Company}

The Company is a renowned company engaged in the manufacture, sale and rental of residential, office, sanitary and storage containers. The Company has of 55 employees and its organizational structure is shown in Fig. 1.

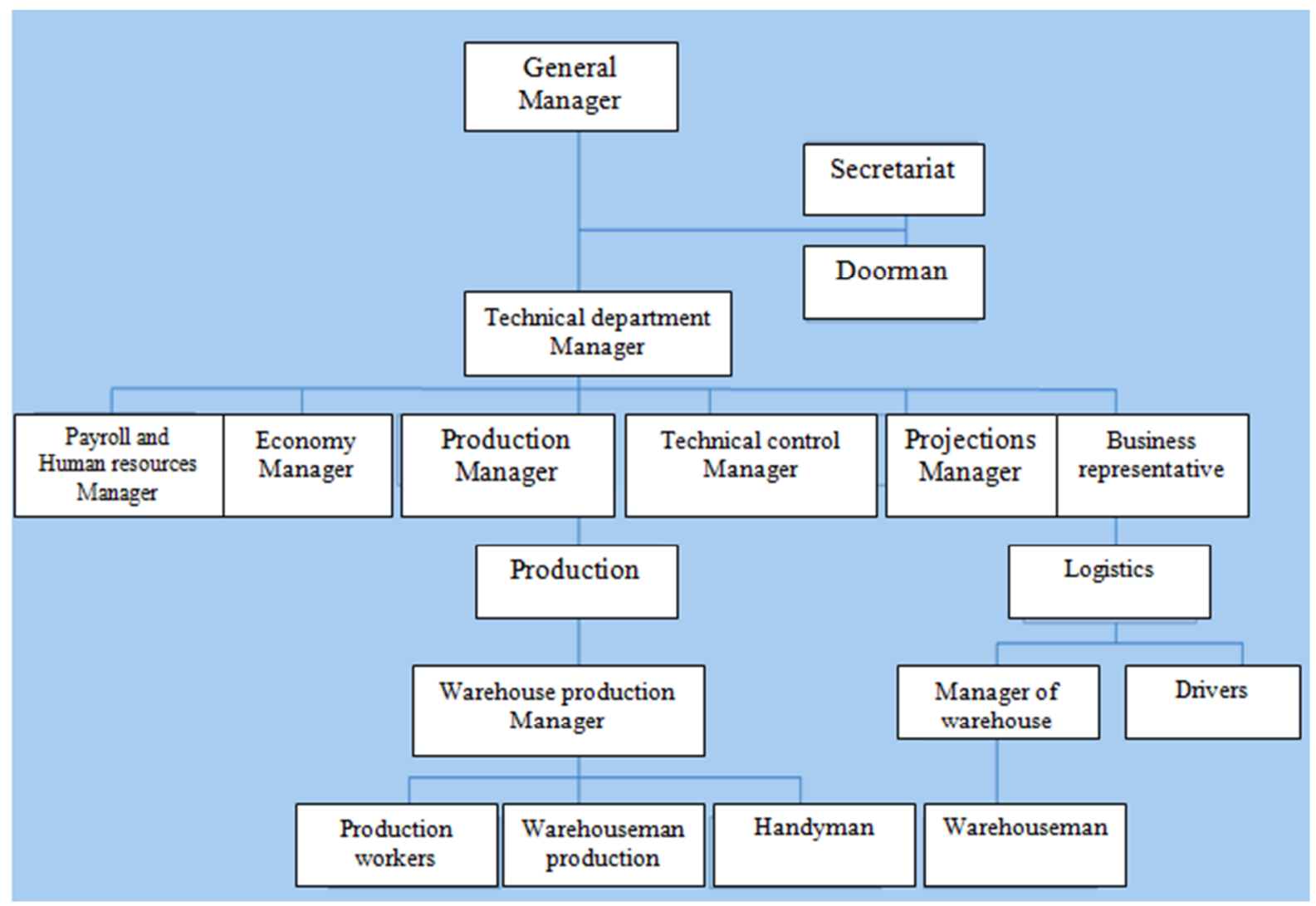

Fig.1: Organizational structure of company [5]

The company is engaged in the production of prefabricated products and assembling of prefabricated constructions. The prefabricated products are characterized by high quality manufacturing and by converting themselves, they meets all the requirements of modern construction. The Company proved the ability to adapt to different conditions of standards of individual countries. Each product is different from the production requirements and customer demands. 


\subsection{Documentation of quality}

It is required from the organisation to carry out, document, establish, sustain and perpetually improve effectively of the system of management of quality according to the standards requirements. The Tab. 1 includes a list of required norm.

\begin{tabular}{l}
\hline A statement of the quality policy and quality objectives \\
\hline Manual of quality \\
The procedures required by the standard \\
Documents to demonstrate the effective planning, operation and \\
management of operational processes \\
Records of quality
\end{tabular}

Tab.1: Obligatory documentation of quality management system STN EN ISO 9001: 2009 [6]

The documentation has to include a written part of documents as well as documents that the organization needs for ensuring the operational effectiveness and operational management processes. Moreover, the rules for the management of documents and records also have to be set up. In the following Tab. 2 there are shown responsibilities for the management of documents applied in the company. In the last row in the table there is a legend of the used symbols [5].

\begin{tabular}{|l|l|l|l|l|}
\hline & $\begin{array}{l}\text { General } \\
\text { Manager }\end{array}$ & $\begin{array}{l}\text { Technical control } \\
\text { Manager }\end{array}$ & $\begin{array}{l}\text { Authorized } \\
\text { personnel }\end{array}$ & $\begin{array}{l}\text { Production } \\
\text { workers }\end{array}$ \\
\hline Quality Handbook & AP, AS & E, R, O, U & C & - \\
\hline Quality Directive & AP, AS & C & E, R, O, U & O \\
\hline Work Instructions & AP & - & E, R, O, U & O \\
\hline $\begin{array}{l}\text { External documents, } \\
\text { STN, regulations }\end{array}$ & AP & AS & R, O, U & - \\
\hline $\begin{array}{l}\text { Legend: E - elaborate, AS - assess, AP - approve, R - register, U - updates, O - } \\
\text { observes, C - cooperate }\end{array}$ &
\end{tabular}

Tab. 2: Responsibility for the management of documents [5]

\subsection{Monitoring customer satisfaction}

Customer satisfaction with the products of the Company was measured based on a questionnaire survey. Thirty customers were approached. The Company implemented houses, schools and apartments for approached customers. The answer came back from twenty six customers. Customers responded to 12 questions, relating of satisfaction with the products of the Company: [5]

A. Complexity and level of offer.

B. Method of negotiations in contracting.

C. Professional preparedness of workers.

D. Changes and customer requirements in the realization.

E. Compliance with delivery dates.

F. Security of supply. 
G. Overall quality of the product.

H. Quantities.

I. Complaints.

J. Price.

K. The overall impression of the company.

L. The application of ISO 9001 quality system.

They can choose from 6 replies (great, very good, good, satisfactory, unsatisfactory, don't know). Results of the questionnaire survey are processed into Table 3.

\begin{tabular}{ccccccc}
\hline Question & Great & Very good & Good & Satisfactory & Unsatisfactory & Don't know \\
\hline A & 6 & 13 & 5 & 2 & - & - \\
B & 10 & 8 & 8 & - & - & - \\
C & 12 & 10 & 2 & 2 & - & - \\
D & 15 & 5 & 6 & - & - & - \\
E & 6 & 11 & 6 & 3 & - & - \\
F & 8 & 10 & 6 & 2 & - & - \\
G & 10 & 9 & 6 & 1 & - & - \\
H & 6 & 13 & 7 & - & - & - \\
I & 12 & 10 & 4 & - & - & - \\
J & 6 & 12 & 8 & - & - & - \\
K & 15 & 9 & 2 & - & - & - \\
L & 8 & 10 & 8 & - & - & \\
\hline
\end{tabular}

Tab. 3: Customer satisfaction with the products of the Company [5]

For a better overview, the results of the questionnaire survey are shown in the chart (Fig. 2)

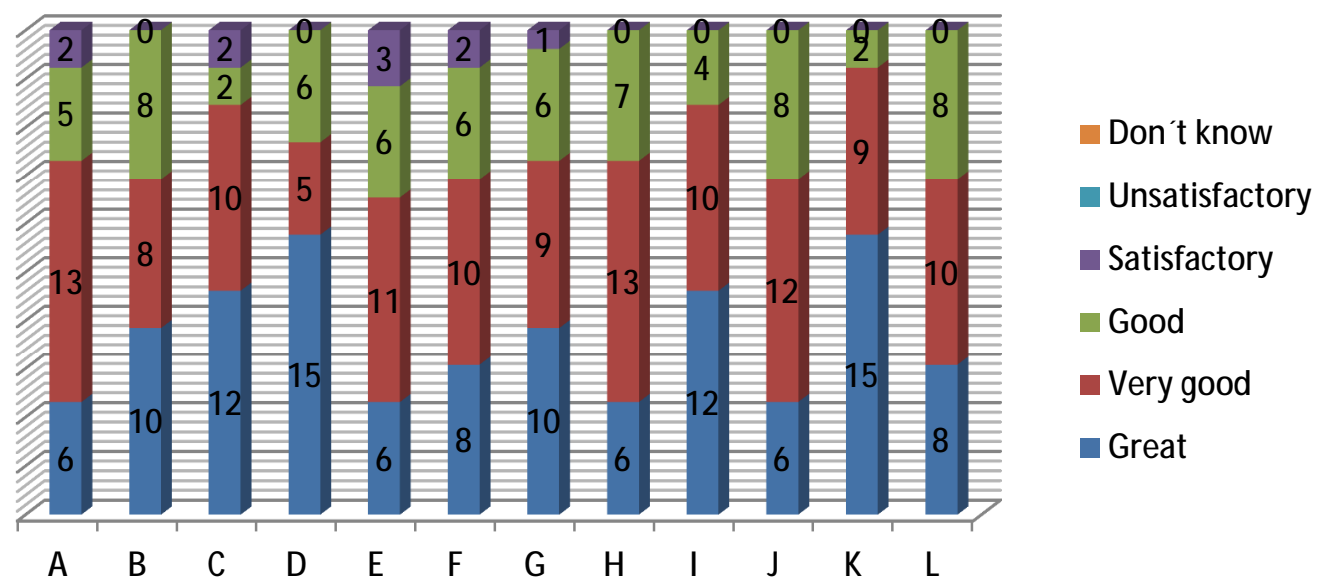

Fig.2: The graphical evaluation of customers' satisfaction with the products of the Company [5]

The questionnaire survey shows that it is necessary for the company to deal mainly with: complexity and level of offer, compliance with delivery dates, quantities and price. 


\section{CONCLUSION}

The implementation of quality control in the selected company is reported in this study. The reasons for the implementation might come from the company itself or from a customer. On the current world market, both manufacturers and consumers require guarantees for the quality of products and services. One of the ways to ensure that the required quality is obtained at appropriate cost and time is by applying quality control in the organization. The aim of this company is to produce high quality and reliable products. The company has opportunity compete in the market and to remain at the market, if has introduction a system of quality assessment and monitoring customer satisfaction with the products.

\section{Acknowledgement}

The article presents a partial research result of project VEGA - 1/0677/14 „Research of construction efficiency improvement through MMC technologies".

The author is grateful to Ing. Miloš Demský from the company RIKOSTAV CONTAINER s.r.o. for the provision of documents, as well as personal consultation.

\section{Literature}

[1] HAIRULLIZA M. J., RUZZAKIAH J., DEVENDRAN G.: Quality Control Implementation in Manufacturing Companies: Motivating Factors and Challenges. Applications and Experiences of Quality Control. Available: www.intechopen.com

[2] CHUNG H. W.: Understanding quality assurance in construction: A practiacal quide to ISO 9000. Available:

http://www.petronet.ir/documents/10180/2323250/Understanding_Quality_Assurance_in_Const ruction_-_A_Practical_Guide_to_ISO_9000_for_Contracto

[3] Selection and use of the ISO 9000 family of standards. 2009. Edition: 3. Available: http://www.iso.org/iso/home/standards/managementstandards/iso_9000.htm

[4] KOZLOVSKÁ M.: Quality of development project management. In: 12. International scientific conference to commemorate the 110th anniversary of the Brno University of Technology and the 14th anniversary of the establishment of the Brno Building Fairs. Section 7 Management building. Brno: CERM, 2009. P. 75-78. - ISBN 9788072046294

[5] RIKOSTAV CONTAINER, s.r.o., Available: http://rikostav.sk/

[6] STN EN ISO 9001: 2008 - The requirements of a quality management system. Available: http://www.sutn.sk/files/Spravy/ISO_9001_web.pdf

[7] MESÁROŠ, P., MANDIČÁK T., MESÁROŠOVÁ M.: Competency-based management of information flows in construction projects. In: SGEM 2014: 14th international multidisciplinary scientific geoconference : GeoConference on Informatics, Geoinformatics and Remote Sensing : conference proceedings : volume 1 : 17-26, June, 2014, Albena, Bulgaria. - Sofia: STEF92 Technology Ltd., 2014 P. 89-96. - ISBN 978-619-7105-10-0 